\title{
Significant distribution extension and first verified record of Chiapan Beaded Lizard, Heloderma alvarezi (Bogert \& Martin del Campo, 1956) (Squamata, Helodermatidae), in southeastern Guerrero, Mexico
}

\author{
Jesús García-Grajales ${ }^{1 *}$, Alejandro Ventura Carmona ${ }^{2}$, César Casiano González ${ }^{2}$, \\ César Ulises Muñóz Valle ${ }^{2}$, Alejandra Buenrostro Silva ${ }^{3}$ \\ 1 Instituto de Recursos, Universidad del Mar campus Puerto Escondido. Km. 2.5, Carretera Federal Puerto Escondido-Sola de Vega, Puerto \\ Escondido 71980, San Pedro Mixtepec, Oaxaca, Mexico•JGG: archosaurio@yahoo.com.mx @ https://orcid.org/0000-0001-6663-0388 \\ 2 Unidad de Manejo y Aprovechamiento Rancho El Capire. Cihuapoloya 41846, Cuautepec, Guerrero, Mexico•AVC:alejandrovc_80@hotmail. \\ com•CCG: cesarcg-ecologo@hotmail.com•UMV: ulises_kouga@hotmail.com \\ 3 Instituto de Industrias, Universidad del Mar campus Puerto Escondido. Km. 2.5, Carretera Federal Puerto Escondido-Sola de Vega, Puerto \\ Escondido 71980, San Pedro Mixtepec, Oaxaca, Mexico•ABS: sba_1575@yahoo.com.mx @ https://orcid.org/0000-0003-3433-0668 \\ * Corresponding author
}

\begin{abstract}
We document the first verifiable records of Heloderma alvarezi (Bogert \& del Campo, 1956) in southeastern Guerrero, Mexico. We recorded seven individuals of $H$. alvarezi near the village of Cihuapoloya, municipality of Cuautepec. These are the westernmost records of the species, extending its distribution by approximately $149 \mathrm{~km}$ from the nearest previously known occurrences in Oaxaca. With these records, the number of reptile species in Guerrero increases to 182.
\end{abstract}

\section{Keywords}

Extent distribution, Helodermatidae, melanism, southern Guerrero, tropical dry forest

\section{Introduction}

Chiapan Beaded Lizard, Heloderma alvarezi (Bogert \& Martin del Campo, 1956), is one of the five species of the family Helodermatidae recorded in Mexico (Campbell and Lamar 2004; Beck 2005). Heloderma alvarezi unique among the beaded lizards because it undergoes an ontogenetic increase in melanism, and the distinctive yellow banding on the tail—which is typical of other species of beaded lizards - is essentially absent in the juveniles and adults of this species (Bogert and Martin del Campo 1956; Beck 2005). Its reported geographic range the central coast of Oaxaca (García-Grajales et al. 2020), Central Depression (Río Grijalva Depression) of central Chiapas, and the Río Lagartero Depression in extreme western Guatemala (Campbell and Lamar 2004; 
Beck 2005; Köhler 2008; Johnson et al. 2010; Wilson and Johnson 2010).

Heloderma alvarezi is a venomous lizard which inhabits seasonally dry tropical deciduous forests (Domínguez-Vega et al. 2012), one of the most threatened ecosystems in the world (Janzen 1988). This species is known colloquially as "escorpión" and is considered extremely dangerous by the local inhabitants. Its natural history is surrounded by mystery, notoriety, and misconception (Reiserer et al. 2013; Domínguez-Vega et al. 2017, 2018), principally because these animals can spend up to $95 \%$ of their lives hidden in shelters underground, which makes detection difficult. Furthermore, studies of population levels are limited. Despite this, it is clear that habitat loss and fragmentation are the main threats to this species because most of its distribution is outside of the well-conserved designated areas where protection is afforded to it (Beck 2005; Domínguez-Vega et al., 2012).

The Mexican state of Guerrero harbors a rich flora and fauna and is considered the fourth most diverse state in the country (Flores-Villela and Gerez 1994; PalaciosAguilar and Flores-Villela 2018). The most recent checklist of the herpetofauna of Guerrero reported 181 reptile species, with only one representative of the family Helodermatidae (Heloderma horridum; Wiegmann, 1829); Palacios-Aguilar and Flores-Villela 2018).

Guerrero has been studied by many researchers, who have reported new species, new state records, and taxonomic changes in the last decades. According to previous studies, the possibility for many other, unreported species in Guerrero exists (Flores-Villela and GarcíaVázquez 2014; Palacios-Aguilar and Flores-Villela 2018). In this study, we provide the first verifiable records of Chiapan Beaded Lizard, H. alvarezi in southeastern Guerrero, Mexico. Our new records come from Cihuapoloya, municipality of Cuautepec, which is an unprotected area in the state.

\section{Methods}

Guerrero is in southern Mexico, and the state has an area of $63,620 \mathrm{~km}^{2}$, which represents $3.2 \%$ of the national territory and makes it the fourteenth largest state in the country (INEGI 2012). There are four biogeographic regions in Guerrero which, from north to south, are Trans-Mexican Volcanic Belt, Balsas Depression, Sierra Madre del Sur, and Pacific Coast (CONABIO 1997).

The southeastern section of the Pacific Coast region is characterized by its forest cover, which is mainly dry forest; however, most areas are highly deforested, and only $2 \%$ of the cover is undisturbed (García 2006). In this region, dry forest has been removed for crops and grasslands, which is one of the principal reasons why this area has been severely affected by anthropogenic change (Trejo 2010). As with most regions of the world, the two main agents of anthropogenic changes are the expansion of large-scale commercial agriculture and increased urbanization (Trejo 2010).
In this region, tropical dry forest is the most extensive forest cover in the state; however, this is found in patches, and the matrix surrounding the forest patches is highly heterogeneous, being composed of secondary forests, annual crops, cattle pastures, and human settlements, as well as rubber, cocoa and oil palm plantations (Torres-Colín 2004). According to the Köppen climatic classification, Cuautepec is within the Tropical Equatorial Climate, with a mean annual temperature of 24-28 ${ }^{\circ} \mathrm{C}$, a mean rainfall of $2245 \mathrm{~mm}$ (García 1973), and a long period of drought that lasts from November to May (Trejo 2010).

We recorded seven Heloderma alvarezi near the village of Cihuapoloya, Cuautepec municipality, Guerrero, where they were encountered by humans during 2020 . We captured each individual and photographed them with an Iphone XR, measured the total length (TL) with a plastic ruler, and weighed each lizard using a 5-kg Pesola handy spring scale balance. The photographs of the captured individuals were deposited in the photographic digital collection of the Colección Nacional de Anfibios y Reptiles in the Instituto de Biología at the Universidad Nacional Autónoma de México (CNAR-IBH-RF).

We used information from scientific collections (e.g., Instituto de Biología, El Colegio de la Frontera Sur) and data available in published literature to determine the currently known distribution of $H$. alvarezi in Mexico. Only reliable information and accurate coordinates from scientific institutions and scientific literature was considered and summarized in a table (Table 1) and a map (Fig. 1), which was prepared using QGIS3.16.

\section{Results}

Our review of collections and literature revealed 30 records of Heloderma alvarezi (Table 1), including our records; $66.6 \%$ were from Chiapas, $23.4 \%$ from Guerrero, and the remaining 10\% from Oaxaca. Our new records (Fig. 1) increase the distribution of the species by $149 \mathrm{~km}$ from the nearest records in Oaxaca. All individuals photographed were encountered between July and September 2020.

New records. MEXICO - Guerrero • $3.02 \mathrm{~km} \mathrm{SE} \mathrm{of}$ Cihuapoloya, Cuautepec municipality; $16^{\circ} 42^{\prime} 10.93^{\prime \prime} \mathrm{N}$, $098^{\circ} 50^{\prime} 30.30^{\prime \prime} \mathrm{W}$; $180 \mathrm{~m}$ a.s.1.; 21.VII.2020; A. VenturaCarmona \& C. Casiano-González leg.; between stacked rocks (1146 h); 1 adult female, CNAR-IBH-RF 639 • $2.08 \mathrm{~km}$ SE of Cihuapoloya, Cuautepec municipality; $16^{\circ} 42^{\prime} 27.17^{\prime \prime} \mathrm{N}, 098^{\circ} 53^{\prime} 13.09^{\prime \prime} \mathrm{W}$; 181 m a.s.1.; 21.VII.2020; A. Ventura-Carmona \& C. Casiano-González leg.; near a cattle pasture (1245h); 1 adult female, CNARIBH-RF 640 • $3.04 \mathrm{~km} \mathrm{SW}$ of Cihuapoloya, Cuautepec municipality; $16^{\circ} 42^{\prime} 13.46^{\prime \prime} \mathrm{N}, \quad 098^{\circ} 53^{\prime} 02.91^{\prime \prime} \mathrm{W}$; $180 \mathrm{~m}$ a.s.l.; 22.VII.2020; A. Ventura-Carmona \& C. Casiano-González leg.; near a cattle pasture (1030 h); 1 adult female, CNAR-IBH-RF $641 \cdot 2.62 \mathrm{~km} \mathrm{SW}$ of Cihuapoloya, Cuautepec municipality; $16^{\circ} 43^{\prime} 00.32^{\prime \prime} \mathrm{N}$, 
Table 1. Locality records of Heloderma alvarezi from Mexico, derived from literature records, official institutions and the present study. Coordinates and localities from only reliable sources are shown. Abbreviations: $\mathrm{CHIS}=\mathrm{Chiapas;} \mathrm{OAX}=\mathrm{Oaxaca}$; GRO = Guerrero. AMNH = American Museum of Natural History; TNHC = Texas Natural History Collection; ECO-SCH = El Colegio de la Frontera Sur- Unidad San Cristobal; UIMNH = Illinois University, Museum of Natural History; UTA-R = University of Texas at Arlington, Collection of Vertebrates; IBUNAM = Instituto de Biología, Universidad Nacional Autónoma de México; MCZ = Harvard University Museum of Comparative Zoology; MZFC = Museo de Zoología, Facultad de Ciencias, Universidad Nacional Autónoma de México; USNM = United State National Museum of Natural History; UTEP = University of Texas at El Paso, Laboratory of Environmental Biology.

\begin{tabular}{|c|c|c|c|c|}
\hline Locality & State & Latitude & Longitude & Reference \\
\hline Cintalapa municipality & CHIS & 16.4140 & -093.4330 & AMNH-65863 \\
\hline Cintalapa municipality & CHIS & 16.4140 & -093.4330 & AMNH-70538 \\
\hline Cintalapa municipality & CHIS & 16.4216 & -093.4813 & AMNH-70540 \\
\hline Cintalapa municipality & CHIS & 16.4216 & -093.4813 & TNHC-23714 \\
\hline Osumacinta municipality & CHIS & 16.5040 & -093.0435 & AMNH-70539 \\
\hline Ocozocoautla de Espinosa municipality & CHIS & 16.4615 & -093.2613 & AMNH-71081 \\
\hline Ocozocoautla de Espinosa municipality & CHIS & 16.3702 & -093.2545 & ECO-SCH-1548 \\
\hline Cintalapa municipality & CHIS & 16.3436 & -093.5533 & UIMNH-7029 \\
\hline Cintalapa municipality & CHIS & 16.2840 & -094.0450 & UTA-R-5715 \\
\hline Cintalapa municipality & CHIS & 16.2840 & -094.0450 & UTA-R-18694 \\
\hline Puerto Arista, Tonala municipality & CHIS & 15.5601 & -093.4837 & IBUNAM-3654 \\
\hline Tonala municipality & CHIS & 16.0530 & -093.4510 & MCZ \\
\hline Tonala municipality & CHIS & 15.5634 & -093.3807 & MZFC-5011 \\
\hline Tonala municipality & CHIS & 15.5104 & -093.2845 & USNM-192535 \\
\hline Tonala municipality & CHIS & 15.5100 & -093.2630 & LACM-38214 \\
\hline Tuxtla Gutiérrez municipality & CHIS & 16.4502 & -093.0703 & IBUNAM-763 \\
\hline Tuxtla Gutiérrez municipality & CHIS & 164502 & -0930703 & IBUNAM-764 \\
\hline \multirow[t]{2}{*}{ Tuxtla Gutiérrez municipality } & CHIS & 16.4745 & -093.0540 & \\
\hline & & & & UTEP-4622 \\
\hline Chiapa de Corzo municipality & CHIS & 16.4354 & -093.0200 & UTA-R \\
\hline Jiquipilas municipality & CHIS & 16.2355 & -093.4911 & ECO-SCH-3275 \\
\hline Santa Rosa de Lima, Villa de Tututepec municipality & OAX & 16.0642 & -097.3745 & García-Grajales et al. 2020 \\
\hline El Porvenir, Santa María Colotepec municipality & OAX & 15.4944 & -096.5829 & García-Grajales et al. 2020 \\
\hline Santa María Huatulco municipality & OAX & 15.4638 & -096.0934 & García-Grajales et al. 2020 \\
\hline Cihuapoloya, Cuautepec munipality & GRO & 16.4300 & -098.5311 & IBH-RF 639, CNAR/this study \\
\hline Cihuapoloya, Cuautepec munipality & GRO & 16.4210 & -098.5030 & IBH-RF 640, CNAR/this study \\
\hline Cihuapoloya, Cuautepec munipality & GRO & 16.4227 & -098.5313 & IBH-RF 641, CNAR/this study \\
\hline Cihuapoloya, Cuautepec munipality & GRO & 16.4251 & -098.5259 & IBH-RF 642 CNAR/this study \\
\hline Cihuapoloya, Cuautepec munipality & GRO & 16.4157 & -098.5039 & IBH-RF 643, CNAR/this study \\
\hline Cihuapoloya, Cuautepec munipality & GRO & 16.4213 & -098.5102 & IBH-RF 644, CNAR/this study \\
\hline Cihuapoloya, Cuautepec munipality & GRO & 16.3909 & -098.5249 & IBH-RF 645 , CNAR/this study \\
\hline
\end{tabular}

098 53'11.88"W; 178 m a.s.1.; 24.VII.2020; A. VenturaCarmona \& C. Casiano-González leg.; on a tree (1830 h); 1 adult female, CNAR-IBH-RF $642 \cdot 2.11 \mathrm{~km} \mathrm{SW}$ of Cihuapoloya, Cuautepec municipality; $16^{\circ} 39^{\prime} 09.40^{\prime \prime} \mathrm{N}$, $098^{\circ} 52^{\prime} 49.36^{\prime \prime} \mathrm{W}$; $168 \mathrm{~m}$ a.s.1.; 24.VII.2020; A. VenturaCarmona \& C. Casiano-González leg.; under a dry tree (1145 h); 1 adult female, CNAR-IBH-RF $643 \cdot 2.11 \mathrm{~km} \mathrm{SW}$ of Cihuapoloya, Cuautepec municipality; 16 $42^{\prime} 51.19^{\prime \prime} \mathrm{N}$, 098 52'59.92"W; 180 m a.s.1.; 30.VII.2020; A. VenturaCarmona \& C. Casiano-González leg.; near a ranch (0915 h); 1 adult female, CNAR-IBH-RF $644 \cdot 7.5$ km S of Cihuapoloya, Cuautepec municipality; $16^{\circ} 41^{\prime} 57.89^{\prime \prime} \mathrm{N}$, 098 50'39.12"W; $180 \mathrm{~m}$ a.s.1.; 26.IX.2020; A. VenturaCarmona \& C. Casiano-González leg.; near a ranch (0800 h); 1 adult female, CNAR-IBH-RF 644.

Identification. The specimens were identified following Beck's (2005) procedure, mainly because this taxon is unique among beaded lizards by undergoing an ontogenetic increase in melanism (Bogert and Martin del Campo 1956; Beck 2005). Our photographic evidence was corroborated by Victor Hugo Reynoso Rosales from the National Collection of Amphibians and Reptiles (CNAR-IBH-RF). All specimens were adult black females (Fig. 2) of different lengths. Although Bogert and Martin del Campo (1956) and Beck (2005) explained that black specimens are uncommon, there is recent photographic evidence (García-Grajales et al. 2020), such our new records here, that proves otherwise.

\section{Discussion}

Our new records of Heloderma alvarezi extend the range by $149 \mathrm{~km}$ to the western of the nearest previously known occurrence at San Pedro Tututepec in the state of Oaxaca (García-Grajales et al. 2020). These new records thus represent the westernmost occurrences of this species in Mexico. The discovery of this species in the municipality of Cuautepec, Guerrero, increases the distribution northwest from the nearest populations in Oaxaca and Chiapas. Although H. alvarezi was thought to be restricted to the Mexican state of Chiapas and adjacent 


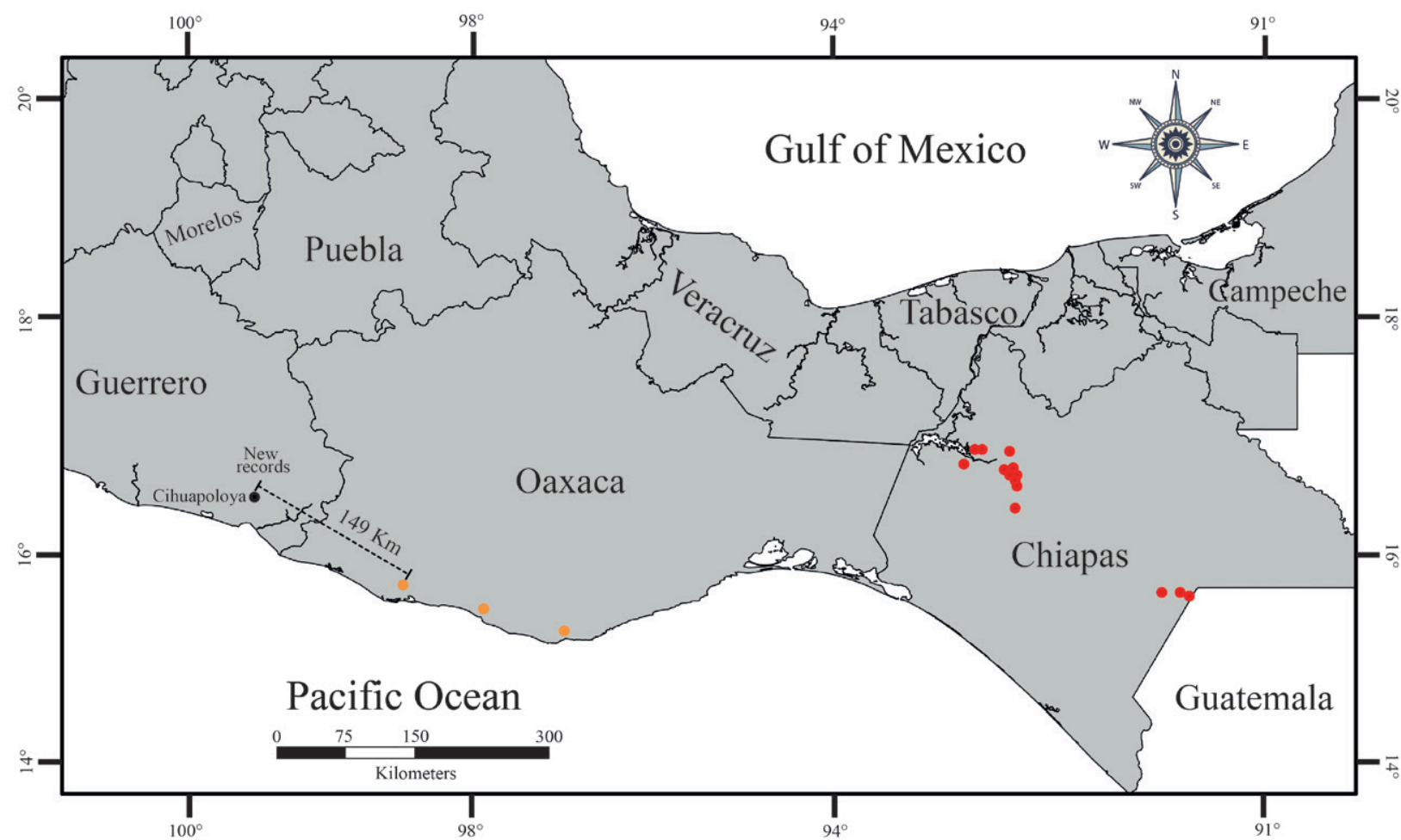

Figure 1. Geographic distribution of Heloderma alvarezi in Mexico. Red dots: historical records; orange dots: literature records; black dots: new records (this study).

western Guatemala, recent evidence has shown it to have a coastal distribution in the state of Oaxaca (García-Grajales et al. 2020). Reiserer et al. (2013) reported an isolated population resembling $H$. alvarezi from San Pedro Tututepec, Oaxaca, but they refrained from calling it this species until the possibility of human displacement could be ruled out.

Our new data are the first verifiable records of $H$. alvarezi from the state of Guerrero and increase the number of reptile species to 182 (Palacios-Aguilar and Flores-Villela 2018). We identified the species using photographic evidence, and this was confirmed by a specialist at CNAR-IBH-RF. Photographic-records are an important tool for documenting the reptiles' presence in a given location (Nguyen et al. 2020), and their scientific significance is increased when they are accompanied with geographic coordinates, habitat characteristics, and other data and deposited into a scientific collection (Casper et al. 2015).

Due to taxonomic changes in the family Helodermatidae in the last decade, $H$. alvarezi is not listed in Mexico (NOM-059-SEMARNAT-2010; SEMARNAT 2010), and in the International Union for Conservation of Nature Red List. In both cases, this is due to the outdated taxonomy of the $H$. horridum complex. The main threat to beaded lizard populations is deforestation of dry tropical forests for agriculture, cattle ranching, and the burgeoning human population (Beck and Lowe 1991; Domínguez-Vega et al. 2012), but the escalation of droughts and fires is also a threat (Beck 2005; Domínguez-Vega et al. 2012; Ariano et al. 2020).

Campbell and Vannini (1988) indicated the probability of areas of intergradation between $H$. horridum and $H$. alvarezi in the region between the Isthmus of Tehuatepec (Oaxaca) and Cintalapa (Chiapas). In an unpublished thesis, Hernández-Jiménez (2011) reported black individuals of Heloderma from Copala, Guerrero, and some localities on the western coast of Oaxaca. In that work, Hernández-Jiménez (2011) found low genetic divergence and geographic structure in these populations and considers that they might represent an undescribed species. Taking this into account, we hypothesize the probable existence of hybridization among wild populations between $H$. horridum and $H$. alvarezi, and we note that additional studies to clarify the extent of hybridization and the forces driving hybridization in southern of Mexico are warranted.

\section{Acknowledgements}

We are grateful to Victor Hugo Reynoso Rosales of the Colección Nacional de Anfibios y Reptiles (CNAR) for corroborating the identification of the species and to the Colección Herpetológica ECOSUR Unidad San Cristobal, Chiapas, for records of $H$. alvarezi. In addition, we special thank A.T. Rosewicz for her revision to the English manuscript. JGG thanks the Sistema Nacional de Investigadores (SNI) for a grant. Finally, two anonymous reviewers made comments that helped to improve the present document.

\section{References}

Ariano-Sánchez D, Mortensen RM, Reinhardt S, Rosell F (2020) Escaping drought: seasonality effects on home range, movement patterns and habitat selection of the Guatemalan Beaded Liz- 

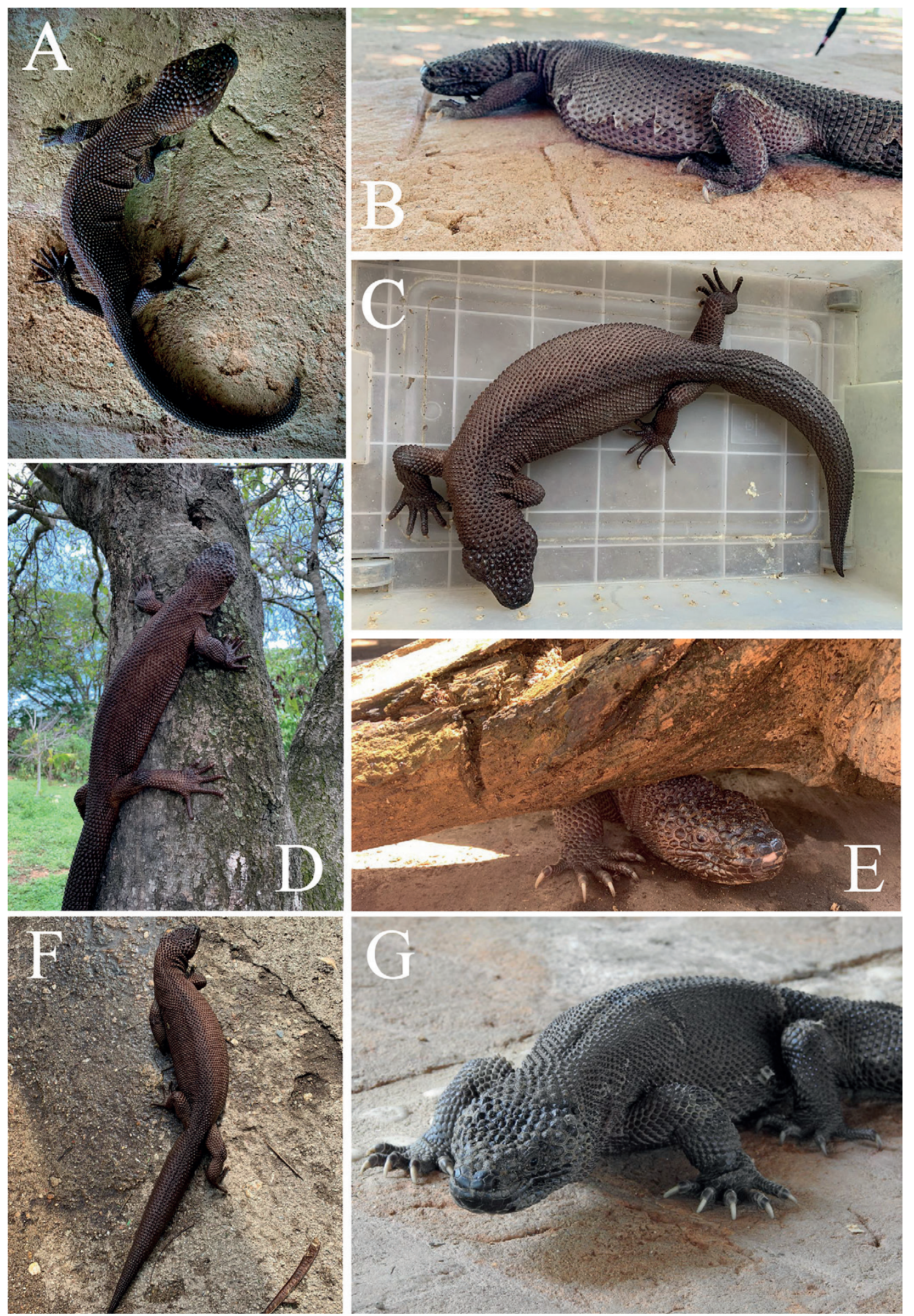

Figure 2. Heloderma alvarezi from municipality of Cihuapoloya, Cuautepec, southeastern Guerrero, Mexico. A. Dorsal view of IBH-RF 639. B. Lateral view of IBH-RF 640. C. Dorsal view IBH-RF 641. D. Lateral view of IBH-RF 642. E. Head of IBH-RF 643. F. Dorsal view of IBH-RF 644. G. Frontal view of IBH-RF 645 . 
ard. Global Ecology and Conservation 23: e01178. https://doi.org/ 10.1016/j.gecco.2020.e01178

Beck DD (2005) Biology of Gila monsters and beaded lizards. University of California Press, Berkeley, California, USA, 247 pp.

Beck DD, Lowe CH (1991) Ecology of the beaded lizard, Heloderma horridum in a tropical dry forest in Jalisco, Mexico. Journal of Herpetology 25: 395-406.

Bogert CM, Martin del Campo R (1956) The Gila monster and its allies: the relationships, habits, and behaviour of the lizards of the family Helodermatidae. Bulletin of the America Museum of Natural History 109: 1-238.

Campbell JA, Vannini JP (1988) A new species of beaded lizard, Heloderma horridum, from the Montagua Valley of Guatemala. Journal of Herpetology 22: 457-468.

Campbell JA, Lamar WW (2004) The venomous reptiles of the Western Hemisphere (2 volumes). Comstock Publishing Associates, Cornell University Press, Ithaca, New York, USA, 528 pp.

Casper GS, Rutherford RD, Anton TG (2015) Baseline distribution records for amphibians and reptiles in the upper Peninsula of Michigan. Herpetological Review 46: 391-406.

Comisión Nacional para el Conocimiento y Uso de la Biodiversidad (CONABIO) (1997) Provincias biogeográficas de México. Scale 1: 4,000,000. Comisión Nacional para el Conocimiento y Uso de la Biodiversidad, México, DF, México.

Domínguez-Vega $\mathrm{H}$, Monroy-Vilchis O, Balderas-Valdivia CJ, Gienger CM, Ariano-Sánchez D (2012) Predicting the potential distribution of the beaded lizard and identification of priority areas for conservation. Journal of Nature Conservation 20: 247-253. https://doi.org/10.1016/j.jnc.2012.04.003

Domínguez-Vega $\mathrm{H}$, Monroy-Vilchis O, Majarrez J, BalderasValdivia CJ (2017) Aversive hunting and sight frequency ecology of beaded lizards (Squamata: Helodermatidae). Perspective in Ecology and Conservation 15: 47-51. https://doi.org/10.1016/j. pecon.2016.11.003

Domínguez-Vega H, Balderas-Valdivia CJ, Manjarrez J, MonroyVilchis O (2018) Conociendo al lagarto escorpión: leyendas, realidad y potencial de una rareza biológica. Ciencia Ergo-sum 25 (2) 1-8. https://doi.org/10.30878/ces.v25n2a10

Flores-Villela O, Gerez P (1994) Biodiversidad y conservación en México: vertebrados, vegetación y uso de suelo. 2nd Edition. CONABIO, DF, México, 439 pp.

Flores-Villela O, García-Váquez U (2014) Biodiversidad de reptiles en México. Revista Mexicana de Biodiversidad 85: 467-475.

García E (1973) Los climas de México. Instituto de Geografía, Universidad Nacional Autónoma de México, México, 75 pp.

García A (2006) Using ecological niche modeling to identify hotspots for the herpetofauna of the Pacific lowlands and adjacent interior valleys of Mexico. Biological Conservation 130: 25-46.

García-Grajales J, Arrazola-Bohórquez R, Penguilly Macías MA, Buenrostro Silva A (2020) New records of Heloderma alva rezi (Wiegmann, 1829) (Sauria: Helodermatidae) on the coast of Oaxaca and increases to its distribution in Mexico. Journal of Threatened Taxa 12 (4): 15495-15598. https://doi.org/10.11609/ jott.5691.12.4.15495-15498

Hernández Jiménez, CA. 2011. Filogenia del género Heloderma. Master's thesis, Universidad Nacional Autónoma de México, México, DF, Mexico, 71 pp. http://132.248.9.195/ptb2011/agosto/0671537/ Index.html. Accessed on: 2021-8-16.

INEGI (Instituto Nacional de Estadística, Geografía e Informática) (2012) Anuario Estadístico de Guerrero 2012. Instituto Nacional de Estadística, Geografía e Informática, Gobierno del Estado de Guerrero, México, $162 \mathrm{pp}$

Janzen DH (1988) Tropical dry forest: the most endangered major tropical ecosystem. In: Wilson EO (Ed.) Biodiversity. National Academy Press, Washington, DC, USA, 130-137.

Johnson JD, Mata-Silva V, Wilson LD (2010) Geographic distribution and conservation of the herpetofauna of southeastern Mexico. In: Wilson LD, Townsend J, Johnson JD (Eds.) Conservation of Mesoamerican amphibians and reptiles. Eagle Mountain Publishing, Utah, USA, 322-369.

Köhler G (2008) Reptiles of Central America. Herpeton, Offenbach, Germany, $812 \mathrm{pp}$

Nguyen TV, Brakels P, Maury N, Sudavanh S, Pawangkhanant P, Idiiatullina S, Lorphengsy S, Inkhavilay K, Suwannapoom C, Poyarkov NA (2020) New herpetofaunal observations from Laos based on photo records. Amphibian \& Reptile Conservation 14: 218 249.

Palacios-Aguilar R, Flores-Villela O (2018) An updated checklist of the herpetofauna from Guerrero, Mexico. Zootaxa 4422 (1): 001024. https://doi.org/10.11646/zootaxa.4422.1.1

Reiserer RS, Schuett, GWS, Beck D (2013) Taxonomic reassessment and conservation status of the beaded lizard, Heloderma horridum (Squamata: Helodermatidae). Amphibian \& Reptiles Conservation 7 (1): 74-96.

Torres-Colín R (2004) Tipos de vegetación. In: García-Mendoza AJ, Ordoñez-Díaz MA, Briones Salas M (Eds.) Biodiversidad de Oaxaca. Universidad Nacional Autónima de México, Fondo Oaxaqueño para la Conservación de la Naturaleza, World Wildlife Fund, México, 105-117.

Trejo I (2010) Las selvas secas de Pacífico Mexicano. In: Ceballos G, Martínez L,García A, Espinoza E, Bezaury JC, Dirzo R (Eds.) Diversidad, amenazas y áreas prioritarias para la conservación de las selvas secas del Pacífico de México. Fondo de Cultura Económica, Comisión Nacional para el Conocimiento y Uso de la Biodiversidad, México, 41-51.

Wilson EO, Johnson JD (2010) Distributional patterns of the herpetofauna of Mesoamerica, a biodiversity hotspot. In: Wilson LD, Townsend JH, Johnson JD (Eds.) Conservation of Mesoamerican amphibians and reptiles. Eagle Mountains, Utah, USA, 30255 . 